\title{
Soil Test Crop Response Based Integrated Plant Nutrition System for Maize on Vertisol
}

\author{
R. Suresh ${ }^{*}$ and R. Santhi \\ Department of Soil Science \& Agricultural Chemistry, Tamil Nadu Agricultural University, \\ Coimbatore (Tamil Nadu), India \\ *Corresponding author
}

\section{A B S T R A C T}

Soil Test Crop Response correlation studies under Integrated Plant Nutrition System (STCR-IPNS) were conducted for maize on Vertisol based on Inductive cum Targeted yield model at Southern Zone of Tamil Nadu during 2016-17. After the establishment of three different soil fertility gradients in the same experimental field, 24 treatments

\section{Keywords}

STCR-IPNS, Vertisol, Maize, Fertilizer Prescription

Article Info

Accepted:

10 July 2018

Available Online:

10 August 2018 comprising different combinations of $\mathrm{N}, \mathrm{P}_{2} \mathrm{O}_{5}, \mathrm{~K}_{2} \mathrm{O}$ and $\mathrm{FYM}$ (four levels each of fertiliser $\mathrm{N}, \mathrm{P}_{2} \mathrm{O}_{5}$ and $\mathrm{K}_{2} \mathrm{O}$ and three levels of $\mathrm{FYM}$ ) were superimposed over the three fertility strips in a Fractional Factorial Design with the test crop maize (TNAU maize hybrid CO 6). The results of the present investigation clearly revealed that there was a progressive increase in response with increase in fertilizer $\mathrm{N}\left(300 \mathrm{~kg} \mathrm{ha}^{-1}\right), \mathrm{P}_{2} \mathrm{O}_{5}\left(120 \mathrm{~kg} \mathrm{ha}^{-1}\right)$ and $\mathrm{K}_{2} \mathrm{O}$ (120 $\left.\mathrm{kg} \mathrm{ha}^{-1}\right)$ levels. Therefore, using the experimental data, the basic parameters viz., (i) the requirement of $\mathrm{N}, \mathrm{P}_{2} \mathrm{O}_{5}$ and $\mathrm{K}_{2} \mathrm{O}$ for maize was found to be $2.08,0.73$ and $1.38 \mathrm{~kg} \mathrm{q}^{-1}$, respectively (ii) the per cent contribution of nutrients from soil (Cs) was 43.01, 44.03 and 9.17; from fertilizers (Cf) was 55.00, 49.83 and 76.99 and from farm yard manure (Co) was $49.01,19.71$ and 39.83 for $\mathrm{N}_{2} \mathrm{P}_{2} \mathrm{O}_{5}$ and $\mathrm{K}_{2} \mathrm{O}$, respectively. Making use of the basic parameters, fertiliser prescription equations (FPEs) have been developed and ready reckoner of fertiliser doses was formulated for desired yield targets of maize for a range of soil test values on Vertisol. The findings brought forth the fact that when farm yard manure (FYM) was applied @ $12.5 \mathrm{t} \mathrm{ha}^{-1}$ (with 25\% moisture and $0.54,0.26$ and $0.53 \%$ NPK, respectively), 45, 22 and $32 \mathrm{kgha}^{-1}$ of fertilizer $\mathrm{N}, \mathrm{P}_{2} \mathrm{O}_{5}$ and $\mathrm{K}_{2} \mathrm{O}$ could be reduced from the recommended fertiliser doses for maize.

\section{Introduction}

Maize (Zea mays L.) called "Queen of cereals" is one of the major cereal crop with wide adaptability to diverse agro-climatic conditions globally and stands first with respect to production in the world and in India, it ranks third after rice and wheat. Maize being an exhaustive crop, the nutrient requirement cannot be supplied through native nutrient reserves, and hence the additional nutrient requirement has to be met from fertiliser inputs (Shreenivas et al., 2017). Efficient nutrient management necessitates balanced fertilizer use, sound management decisions and practices to the productivity of maize and sustained soil fertility (Sivaranjani et al., 2018). The area under maize cultivation 
was 93.6 million hectares accounting to 9.8 percent of the total cultivated area of the world (Giri and Ramana Reddy, 2015). In India, during 2015-16, maize was cultivated in 8.69 million hectares with an average productivity of $2580 \mathrm{~kg} \mathrm{ha}^{-1}$ while in Tamil Nadu, it was cultivated in an area of 3.64 lakh ha with a production of 23.83 million tones and productivity of $6549 \mathrm{kgha}^{-1}$.

Among the various methods of fertiliser recommendations, the one based on yield targeting is unique because this method not only considers the soil test based fertilizer dose but also the level of yield the farmer can achieve if good agronomic practices are followed to raise the crop. This targeted yield approach is also scientifically sound as the balanced fertilisation is ensured not only among the fertiliser nutrients but also the soil available nutrients (Veeranna and Srijaya, 2017). At this juncture, the prescription procedure outlined by Troug (1960) and modified by Ramamoorthy et al., (1967) as "Inductive-cum-Targeted yield model" provides a scientific basis for balanced fertilization and balance between the applied nutrients and available nutrients. Based on this concept, Soil Test Crop Response correlation studies under Integrated Plant Nutrition system (STCR-IPNS) were undertaken in different parts of India (Dey and Bhogal, 2016) and Tamil Nadu (Santhi et al., 2017) and fertilizer prescriptions have been derived for desired yield targets of various major field and horticultural crops on different soil types. Though soil test based fertilizer prescriptions for various soil types and agro-climatic zones in different parts of Tamil Nadu, STCR studies has not yet been carried out for maize in Vertisol Keeping the above facts in view, the present investigation on Soil Test Crop Response based Integrated Plant Nutrition System was undertaken on Pilamedu soil series (Typic Haplustert) in Southern zone of Tamil Nadu.

\section{Materials and Methods}

The field experiment was carried out in 20162017 kharif season at farmer holding Manikapuram village of Bodinayakanur taluk, Theni District in Southern zone of Tamil Nadu state, which falls between $9^{0} 48^{\prime} \mathrm{N}$ latitude and $77^{\circ} 25^{\prime} \mathrm{E}$ longitude. The soil of the experimental field was deep, black calcareous, moderately drained and clayey. The $\mathrm{pH}$ of the soil was slightly alkaline, non-saline and available $\mathrm{N}, \mathrm{P}$ and $\mathrm{K}$ status was low, medium and high respectively. With regard to available micronutrients, sufficient range of iron $(\mathrm{Fe})$, manganese $(\mathrm{Mn})$ and deficient range of zinc $(\mathrm{Zn})$ and copper $(\mathrm{Cu})$ were recorded.

\section{Phase-I-Gradient experiment}

The experiment was conducted according to the approved layout plan of All India Coordinated Research Project on Soil Test Crop Response (STCR) and a unique experimental technique (inductive methodology) developed by Ramamoorthy et al., (1967) was adopted in the present investigation. For this purpose, the experimental field was divided into three equal strips and denoted as Strip I (SI), Strip II(SII) and Strip III (SIII)viz., $\mathrm{N}_{0} \mathrm{P}_{0} \mathrm{~K}_{0}, \mathrm{~N}_{1} \mathrm{P}_{1} \mathrm{~K}_{1}$ and $\mathrm{N}_{2} \mathrm{P}_{2} \mathrm{~K}_{2}$ respectively. Fertility gradients were created by applying the graded doses of fertilizer $\mathrm{N}, \mathrm{P}_{2} \mathrm{O}_{5}$ and $\mathrm{K}$ for obtaining the operational range of soil test values in various soil fertility strips. The standard dose of fertiliser $\mathrm{P}_{2} \mathrm{O}_{5}$ and $\mathrm{K}_{2} \mathrm{O}\left(\mathrm{P}_{1} \mathrm{~K}_{1}\right)$ were fixed based on the phosphorus (100 kg P ha ${ }^{-1}$ ) and potassium $\left(80 \mathrm{~kg} \mathrm{~K} \mathrm{ha}^{-1}\right)$ fixing capacities of the soil and the standard dose of $\mathrm{N}\left(\mathrm{N}_{1}\right)$ was fixed as per the blanket recommendation for fodder sorghum $\left(90 \mathrm{kgha}^{-1}\right)$. Fodder sorghum (var. CO 30) was raised during summer 2016 as an exhaust crop (gradient crop) and an operational range of soil test values in respect of available N, P and $\mathrm{K}$ was created. The data on post-harvest soil available $\mathrm{N}, \mathrm{P}$ and $\mathrm{K}$, 
fodder yield and uptake of N, P and K by fodder sorghum confirmed the creation of soil fertility gradients among the three fertility strips.

\section{Phase-II-test crop experiment}

After the establishment of fertility gradients, in the second phase of the field experiment, each strip was divided into 24 plots so as to accommodate 24 treatments with four levels each of $\mathrm{N}\left(0,100,200\right.$ and $\left.300 \mathrm{~kg} \mathrm{ha}^{-1}\right), \mathrm{P}_{2} \mathrm{O}_{5}$ $\left(0,40,80,120 \mathrm{~kg} \mathrm{ha}^{-1}\right)$ and $\mathrm{K}_{2} \mathrm{O}(0,40,80$, $120 \mathrm{~kg} \mathrm{ha}^{-1}$ ) and the experiment was laid out in fractional factorial design. There were three levels of FYM $\left(0,6.25\right.$ and $\left.12.5 \mathrm{t} \mathrm{ha}^{-1}\right)$ and the IPNS treatments viz., NPK+FYM@6.25 t ha ${ }^{-1}$, NPK+FYM@ $12.5 \mathrm{t} \mathrm{ha}^{-1}$ and NPK alone treatments were super imposed across the strips thus forming a total of 72 plots. The 21 fertilizer treatments and three controls were randomized in such a way that all the 24 treatments were present in all the three strips on both the directions. The treatment structure is given in Table 1. Pre-sowing soil samples were collected from each plot before the application of fertilizers and manures and analyzed for alkaline $\mathrm{KMnO}_{4}-\mathrm{N}$ (Subbiah and Asija, 1956), Olsen-P (Olsen et al., 1954) and $\mathrm{NH}_{4} \mathrm{OAc}-\mathrm{K}$ status (Hanway and Heidal, 1952). The test crop maize (TNAU Maize hybrid CO 6) was raised during July 2016 and the crop was grown to maturity and the grain and stover yields were recorded plot-wise; grain and straw samples from each plot collected, processed and analyzed for total $\mathrm{N}$ (Humphries, 1956), $\mathrm{P}$ and $\mathrm{K}$ (Piper, 1966) contents and the uptake of $\mathrm{N}, \mathrm{P}$ and $\mathrm{K}$ by maize was computed.

\section{Computation of basic parameters}

Making use of data on the yield of maize, total uptake of $\mathrm{N}, \mathrm{P}$ and $\mathrm{K}$, pre-sowing soil test values for available $\mathrm{N}, \mathrm{P}$ and $\mathrm{K}$ and doses of fertiliser $\mathrm{N}, \mathrm{P}_{2} \mathrm{O}_{5}$ and $\mathrm{K}_{2} \mathrm{O}$ applied, the basic parameters viz., nutrient requirement (NR), contribution of nutrients from soil (Cs), fertilisers (Cf) and farmyard manure (Cfym) were calculated as outlined by Ramamoorthy et al., (1967).

\section{Nutrient Requirement (NR)}

$\mathrm{Kg}$ of $\mathrm{N} / \mathrm{P}_{2} \mathrm{O}_{5} / \mathrm{K}_{2} \mathrm{O}$ required per quintal (100 $\mathrm{kg})$ of grain yield production, expressed in $(\mathrm{kg}$ $\left.q^{-1}\right)$.

$\mathrm{NR}=\left(\right.$ Total uptake of $\mathrm{N}$ or $\mathrm{P}_{2} \mathrm{O}_{5}$ or $\mathrm{K}_{2} \mathrm{O}(\mathrm{kg}$ $\left.\mathrm{ha}^{-1}\right)$ ) /Grain yield (q ha $\left.{ }^{-1}\right)$

\section{Per cent contribution of nutrients from soil to total nutrient uptake (Cs)}

Cs $=\left[\left(\right.\right.$ Total uptake of $\mathrm{N}$ or $\mathrm{P}_{2} \mathrm{O}_{5}$ or $\mathrm{K}_{2} \mathrm{O}$ in control plot $\left(\mathrm{kg} \mathrm{ha}^{-1}\right)$ ) / (Soil test value for available $\mathrm{N}$ or $\mathrm{P}_{2} \mathrm{O}_{5}$ or $\mathrm{K}_{2} \mathrm{O}$ in control plot $(\mathrm{kg}$ $\left.\left.\mathrm{ha}^{-1}\right)\right)$ ] 100

\section{Per cent contribution of nutrients from Fertilizer to total nutrient uptake (Cf)}

$\mathrm{Cf}=\left\{\left[\left(\right.\right.\right.$ Total uptake of $\mathrm{N}$ or $\mathrm{P}_{2} \mathrm{O}_{5}$ or $\mathrm{K}_{2} \mathrm{O}$ in treated plot $\left(\mathrm{kg} \mathrm{ha}^{-1}\right)$ ) - (Soil test value for available $\mathrm{N}$ or $\mathrm{P}_{2} \mathrm{O}_{5}$ or $\mathrm{K}_{2} \mathrm{O}$ in control plot $(\mathrm{kg}$ $\mathrm{ha}^{-1}$ ) * Average Cs)] / Fertiliser $\mathrm{N}$ or $\mathrm{P}_{2} \mathrm{O}_{5}$ or $\mathrm{K}_{2} \mathrm{O}$ applied $\left.\left(\mathrm{kg} \mathrm{ha}^{-1}\right)\right\} * 100$

\section{Percent contribution of nutrients from FYM to total nutrient uptake (Cfym)}

Cfym $=\{[($ Total uptake of $\mathrm{N}$ or $\mathrm{P}$ or $\mathrm{K}$ in FYM treated plot $\left.\left(\mathrm{kg} \mathrm{ha}^{-1}\right)\right)-($ Soil test value for available $\mathrm{N}$ or $\mathrm{P}$ or $\mathrm{K}$ in FYM treated plot $\left(\mathrm{kg} \mathrm{ha}^{-1}\right) *$ Average Cs)] / Nutrient N/P/K added through FYM $\left.\left(\mathrm{kg} \mathrm{ha}^{-1}\right)\right\} * 100$

These parameters were used for developing Fertiliser Prescription Equations (FPEs) for deriving fertilizer doses and the soil test based fertilizer recommendations were prescribed in the form of a ready reckoner (nomograms) for 
desired yield target of maize under NPK alone as well as under IPNS.

\section{Fertilizer Prescription Equations}

Making use of these parameters, the Fertilizer Prescription Equations (FPEs) under NPK alone and IPNS were developed for maize as furnished below:

\section{Fertiliser nitrogen (FN)}

$\mathrm{FN}=\{[(\mathrm{NR} /(\mathrm{Cf} / 100)) * \mathrm{~T}]-[(\mathrm{Cs} / \mathrm{Cf}) * \mathrm{SN}]\}$

$\mathrm{FN}=\{[(\mathrm{NR} /(\mathrm{Cf} / 100)) * \mathrm{~T}]-[(\mathrm{Cs} / \mathrm{Cf}) * \mathrm{SN}]-$ $[(\mathrm{Cfym} / \mathrm{Cf}) * \mathrm{ON}]\}$

Fertiliser phosphorus $\left(\mathrm{FP}_{2} \mathrm{O}_{5}\right)$

$\mathrm{FP}_{2} \mathrm{O}_{5}=\{[(\mathrm{NR} /(\mathrm{Cf} / 100)) * \mathrm{~T}] \quad-$ $[(\mathrm{Cs} / \mathrm{Cf}) * 2.29 \mathrm{SP}]\}$

$\mathrm{FP}_{2} \mathrm{O}_{5}=\{[(\mathrm{NR} / \quad(\mathrm{Cf} / 100)) * \mathrm{~T}] \quad-$ $[(\mathrm{Cs} / \mathrm{Cf}) * 2.29 \mathrm{SP}]-[(\mathrm{Cfym} / \mathrm{Cf}) * 2.29 \mathrm{OP}]\}$

Fertiliser potassium $\left(\mathrm{FK}_{2} \mathrm{O}\right)$

$\mathrm{FK}_{2} \mathrm{O}=\{[(\mathrm{NR} /(\mathrm{Cf} / 100)) * \mathrm{~T}]-[(\mathrm{Cs} / \mathrm{Cf}) * 1.21$ $\mathrm{SK}]\}$

$\mathrm{FK}_{2} \mathrm{O}_{5}=\{[(\mathrm{NR} / \quad(\mathrm{Cf} / 100)) * \mathrm{~T}] \quad-$ $[(\mathrm{Cs} / \mathrm{Cf}) * 1.21 \mathrm{SK}]-[(\mathrm{Cfym} / \mathrm{Cf}) * 1.21 \mathrm{OK}]\}$

Where, $\mathrm{FN}, \mathrm{FP}_{2} \mathrm{O}_{5}$ and $\mathrm{FK}_{2} \mathrm{O}$ are fertilizer $\mathrm{N}$, $\mathrm{P}_{2} \mathrm{O}_{5}$ and $\mathrm{K}_{2} \mathrm{O}$ in $\mathrm{kg} \mathrm{ha}^{-1}$, respectively; NR is the nutrient requirement $\left(\mathrm{N}\right.$ or $\mathrm{P}_{2} \mathrm{O}_{5}$ or and $\mathrm{K}_{2} \mathrm{O}$ ) in $\mathrm{kg} \mathrm{q}^{-1}$; Cs is the per cent contribution of nutrients from soil, $\mathrm{Cf}$ is the per cent contribution of nutrients from fertilizer, Cfym is percent contribution of nutrients from FYM, $\mathrm{T}$ is the yield target in $\mathrm{q} \mathrm{ha}^{-1} ; \mathrm{SN}, \mathrm{SP}$ and $\mathrm{SK}$ respectively are alkaline $\mathrm{KMnO}_{4}-\mathrm{N}$, Olsen-P and $\mathrm{NH}_{4} \mathrm{OAc}-\mathrm{K}$ in $\mathrm{kg} \mathrm{ha}^{-1}$ and $\mathrm{ON}, \mathrm{OP}$ and $\mathrm{OK}$ are the quantities of $\mathrm{N}, \mathrm{P}$ and $\mathrm{K}$ supplied through FYM in $\mathrm{kg} \mathrm{ha}^{-1}$. These equations serve as a basis for predicting fertiliser doses for specific yield targets $(\mathrm{T})$ of maize for varied soil available nutrient levels.

\section{Results and Discussion}

Maize grain yield, uptake and pre-sowing available NPK status

The range and mean of soil test values and yield of treated and control plots of maize are presented in Table 2. The results showed that the mean $\mathrm{KMnO}_{4}-\mathrm{N}$, was 163,184 and $199 \mathrm{~kg}$ $\mathrm{ha}^{-1}$ in strip I, II and III respectively. The mean Olsen-P was $19.4,30$ and $37.2 \mathrm{~kg} \mathrm{ha}^{-1}$ in Strip I, II and III respectively. With regard to $\mathrm{NH}_{4} \mathrm{OAc}-\mathrm{K}$, the mean values were 557, 570 and $585 \mathrm{kgha}^{-1}$ in strip I, II and III respectively. The overall mean values of $\mathrm{KMnO}_{4}-\mathrm{N}$, Olsen-P and $\mathrm{NH}_{4} \mathrm{OAc}-\mathrm{K}$ in NPK treated plots were $182,28.9$ and $571 \mathrm{~kg} \mathrm{ha}^{-1}$, respectively. The overall mean values of $\mathrm{KMnO}_{4}-\mathrm{N}$, Olsen-P and $\mathrm{NH}_{4} \mathrm{OAc}-\mathrm{K}$ in control plots were 181, 25.8 and $567 \mathrm{~kg} \mathrm{ha}^{-1}$, respectively.

The grain yield in strip I ranged from 3317 to $9924 \mathrm{~kg} \mathrm{ha}^{-1}$ with a mean value of $7670 \mathrm{~kg} \mathrm{ha}^{-}$ ${ }^{1}$ from 4230 to $10674 \mathrm{~kg} \mathrm{ha}^{-1}$ with a mean of $8660 \mathrm{~kg} \mathrm{ha}^{-1}$ in strip II and in strip III from 4734 to $11187 \mathrm{~kg} \mathrm{ha}^{-1}$ with a mean of $9140 \mathrm{~kg}$ $\mathrm{ha}^{-1}$.The mean grain yield of overall NPK treated and control plots were 8996 and 4918 $\mathrm{kg} \mathrm{ha}^{-1}$, respectively. The percent increase of 82.9 over control was recorded. The $\mathrm{N}$ uptake varied from 68.2 to $248 \mathrm{~kg} \mathrm{ha}^{-1}$, P uptake was from 9.4 to $46.9 \mathrm{~kg} \mathrm{ha}^{-1}$ and the $\mathrm{K}$ uptake varied from 49.9 to $137.6 \mathrm{~kg} \mathrm{ha}^{-1}$ respectively in strip I, II and III. The overall mean values of $\mathrm{N}, \mathrm{P}$ and $\mathrm{K}$ uptake in NPK treated plots were 189.7, 30.2 and $101.6 \mathrm{~kg} \mathrm{ha}{ }^{-1}$, respectively. The mean values of $\mathrm{N}, \mathrm{P}$ and $\mathrm{K}$ uptake in overall control plots were 89.9, 13.7 and 60.5 respectively.

It was evident from the above data that a wide variability has existed in the soil test values 
and grain yield of treated and control plots which is essential for developing the basic parameters and targeted yield equations for calibrating the optimum fertilizer doses. These results are in conformity with the earlier works by Udayakumar and Santhi (2017) for pearl millet on Inceptisol.

\section{Response of maize to fertilizer $\mathrm{N}, \mathrm{P}_{2} \mathrm{O}_{5}$ and $\mathrm{K}_{2} \mathrm{O}$}

The results indicated that maize is an exhaustive crop and requires relatively higher nutrient levels and also enhanced the grain yield $\mathrm{kg} \mathrm{kg}^{-1}$ when there is a constant supply of nutrients. In optimization of fertilizer dose, response of maize to fertilizer levels plays a crucial role. The response of hybrid maize to different graded levels of $\mathrm{N}, \mathrm{P}_{2} \mathrm{O}_{5}$ and $\mathrm{K}_{2} \mathrm{O}$ were assessed in terms of response ratio (RR).

There was an increase response of $\mathrm{N}, \mathrm{P}_{2} \mathrm{O}_{5}$ and $\mathrm{K}_{2} \mathrm{O}$ observed with increase in fertilizer levels. The highest response ratio (RR) of $\mathrm{N}$, $\mathrm{P}_{2} \mathrm{O}_{5}$ and $\mathrm{K}_{2} \mathrm{O}$ observed in $\mathrm{N}_{300}, \mathrm{P}_{120}$ and $\mathrm{K}_{120}$ as $10.33,10.37$ and 9.70 respectively (Table 3). Veeranna and Srijaya (2017) reported that increased level of nitrogen had a significant effect on growth and yield of maize (Giri and Ramana Reddy, 2015) and observed an increase in yield with increased level of $\mathrm{P}_{2} \mathrm{O}_{5}$ application.

Likewise, increase in yield of maize with increase in $\mathrm{K}_{2} \mathrm{O}$ levels was reported by Sidharam Patil et al., (2017).

\section{Basic parameters}

Using the data of grain yield, total N, P and $\mathrm{K}$ uptake by maize and initial soil test values of $\mathrm{N}, \mathrm{P}$ and $\mathrm{K}$, fertilizer doses of $\mathrm{N}, \mathrm{P}_{2} \mathrm{O}_{5}$ and $\mathrm{K}_{2} \mathrm{O}$ and FYM levels, basic parameters viz, nutrient requirement $\left(\mathrm{kg} \mathrm{q}^{-1}\right)$, the percent contribution of nutrients from soil (Cs), fertilizers (Cf) and FYM (Cfym) have been derived (Table 4). Using these basic parameters, targeted yield equations of $\mathrm{N}, \mathrm{P}$ and $\mathrm{K}$ nutrients have been derived under NPK alone and IPNS for computing optimal fertilizer doses for attaining yield targets of 9, 10 and $11 \mathrm{t} \mathrm{ha}^{-1}$. From the perusal of the data it can be inferred that the amount of nutrient required to produce one quintal of maize was $2.08 \mathrm{~kg} \mathrm{~N}, 0.73 \mathrm{~kg} \mathrm{P}_{2} \mathrm{O}_{5}$ and $1.38 \mathrm{~kg} \mathrm{~K}_{2} \mathrm{O}$.

The contribution from soil available nutrients towards nutrient uptake was $43.01 \%$ for $\mathrm{N}$, $44.03 \%$ for $\mathrm{P}_{2} \mathrm{O}_{5}$ and $9.17 \%$ for $\mathrm{K}_{2} \mathrm{O}$. Among the three nutrients, contribution from soil was higher in $\mathrm{P}_{2} \mathrm{O}_{5}$ followed by $\mathrm{N}$ and $\mathrm{K}_{2} \mathrm{O}$.

The contribution from fertilizer nutrient was $55 \%$ for $\mathrm{N}, 49.83$ for $\mathrm{P}_{2} \mathrm{O}_{5}$ and $79.99 \%$ for $\mathrm{K}_{2} \mathrm{O}$. From the data, the contribution from fertilizer was higher than that from the soil and followed the order of $\mathrm{K}_{2} \mathrm{O}>\mathrm{N}>\mathrm{P}_{2} \mathrm{O}_{5}$. The contribution of nutrients from FYM was 49.01, 19.71 and $39.83 \%$ for $\mathrm{N}, \mathrm{P}_{2} \mathrm{O}_{5}$ and $\mathrm{K}_{2} \mathrm{O}$ respectively.

\section{Fertilizer Prescription Equations for desired yield target of maize}

Fertilizer prescription equations were evolved for maize to achieve a definite yield target based on the basic parameters viz., nutrient requirement, percent contribution of nutrients from soil, fertilizers and FYM and the equations are furnished below:

\section{STCR-NPK alone}

$\mathrm{FN}=3.78 \mathrm{~T}-0.78 \mathrm{SN}$

$\mathrm{F}_{2} \mathrm{O}_{5}=1.47 \mathrm{~T}-2.02 \mathrm{SP}$

$\mathrm{F} \mathrm{K}_{2} \mathrm{O}=1.79 \mathrm{~T}-0.14 \mathrm{SK}$

\section{STCR-IPNS (NPK+FYM)}

$\mathrm{FN}=3.78 \mathrm{~T}-0.78 \mathrm{SN}-0.89 \mathrm{ON}$

$\mathrm{FP}_{2} \mathrm{O}_{5}=1.47 \mathrm{~T}-2.02 \mathrm{SP}-0.91 \mathrm{OP}$

$\mathrm{FK}_{2} \mathrm{O}=1.79 \mathrm{~T}-0.14 \mathrm{SK}-0.62 \mathrm{OK}$ 
Int.J.Curr.Microbiol.App.Sci (2018) 7(8): 1631-1641

Table.1 Treatment structure for test crop experiment on Maize

\begin{tabular}{|c|c|c|c|c|c|c|}
\hline \multirow[t]{2}{*}{ SI. No } & \multicolumn{3}{|c|}{ Treatment combination } & \multicolumn{3}{|c|}{ Levels of nutrients ( $\mathrm{kg} \mathrm{ha}^{-1}$ ) } \\
\hline & $\mathbf{N}$ & $\mathbf{P}$ & $\mathbf{K}$ & $\mathbf{N}$ & $\mathbf{P}_{2} \mathrm{O}_{5}$ & $\mathrm{~K}_{2} \mathrm{O}$ \\
\hline 1 & 0 & 0 & 0 & 0 & 0 & 0 \\
\hline 2 & 0 & 0 & 0 & 0 & 0 & 0 \\
\hline 3 & 0 & 0 & 0 & 0 & 0 & 0 \\
\hline 4 & 0 & 2 & 2 & 0 & 80 & 80 \\
\hline 5 & 1 & 1 & 1 & 100 & 40 & 40 \\
\hline$\overline{6}$ & 1 & 2 & 1 & 100 & 80 & 40 \\
\hline 7 & 1 & 1 & 2 & 100 & 40 & 80 \\
\hline 8 & 1 & 2 & 2 & 100 & 80 & 80 \\
\hline 9 & 2 & 1 & 1 & 200 & 40 & 40 \\
\hline 10 & 2 & 0 & 2 & 200 & 0 & 80 \\
\hline 11 & 2 & 1 & 2 & 200 & 40 & 80 \\
\hline 12 & 2 & 2 & 2 & 200 & 80 & 80 \\
\hline 13 & 2 & 2 & 1 & 200 & 80 & 40 \\
\hline 14 & 2 & 2 & 0 & 200 & 80 & 0 \\
\hline 15 & 2 & 2 & 3 & 200 & 80 & 120 \\
\hline 16 & 2 & 3 & 2 & 200 & 120 & 80 \\
\hline 17 & 2 & 3 & 3 & 200 & 120 & 120 \\
\hline 18 & 3 & 1 & 1 & 300 & 40 & 40 \\
\hline 19 & 3 & 2 & 1 & 300 & 80 & 40 \\
\hline 20 & 3 & 2 & 2 & 300 & 80 & 80 \\
\hline 21 & 3 & 3 & 1 & 300 & 120 & 40 \\
\hline 22 & 3 & 3 & 2 & 300 & 120 & 80 \\
\hline 23 & 3 & 2 & 3 & 300 & 80 & 120 \\
\hline 24 & 3 & 3 & 3 & 300 & 120 & 120 \\
\hline
\end{tabular}


Table.2 Initial soil available NPK, yield and NPK uptake by Maize in various strips of test crop experiment $\left(\mathrm{kg} \mathrm{ha}^{-1}\right)$

\begin{tabular}{|c|c|c|c|c|c|c|c|c|c|c|}
\hline \multirow{3}{*}{$\begin{array}{c}\text { Parameters } \\
\left.\text { (kg ha }^{-1}\right)\end{array}$} & \multirow{2}{*}{\multicolumn{2}{|c|}{ Strip I }} & \multirow{2}{*}{\multicolumn{2}{|c|}{ Strip II }} & \multirow{2}{*}{\multicolumn{2}{|c|}{ Strip III }} & \multicolumn{4}{|c|}{ Overall } \\
\hline & & & & & & & \multicolumn{2}{|c|}{ NPK Treated } & \multicolumn{2}{|c|}{ Control (NPK) } \\
\hline & Range & Mean & Range & Mean & Range & Mean & Range & Mean & Range & Mean \\
\hline $\mathrm{KMnO}_{4}-\mathrm{N}$ & $158-166$ & 163 & $178-187$ & 184 & $195-203$ & 199 & $158-203$ & 182 & $158-198$ & 181 \\
\hline Olsen-P & $16-20$ & 19.4 & $26-32$ & 30.0 & $33-39$ & 37.2 & $16-39$ & 28.9 & $16-34$ & 25.8 \\
\hline $\mathrm{NH}_{4} \mathrm{OAc}-\mathrm{K}$ & $553-563$ & 557 & $566-576$ & 570 & $580-588$ & 585 & $553-558$ & 571 & $554-582$ & 567 \\
\hline Grain Yield & $3317-9924$ & 7670 & $4230-10674$ & 8660 & 4734-11187 & 9140 & $6291-11187$ & 8996 & $3317-6836$ & 4918 \\
\hline $\mathbf{N}$ uptake & $68.2-223.7$ & 166.2 & $76.3-234.5$ & 176.7 & $82.1-248.0$ & 188.7 & $123.7-248.0$ & 189.7 & $68.2-110.7$ & 89.9 \\
\hline P uptake & $9.4-42.6$ & 25.4 & $12.1-43.2$ & 28.5 & $13.7-46.9$ & 30.5 & $14.8-46.9$ & 30.2 & $9.4-17.3$ & 13.7 \\
\hline K uptake & $49.9-122.0$ & 89.1 & $52.8-137.8$ & 96.0 & $57.7-137.6$ & 104.3 & 63.4-137.6 & 101.6 & $49.9-73.5$ & 60.5 \\
\hline
\end{tabular}

Table.3 Response of maize to different levels of fertilizer nutrients

\begin{tabular}{|c|c|c|c|c|c|c|c|c|c|}
\hline \multirow{2}{*}{$\begin{array}{l}\text { S. } \\
\text { No. }\end{array}$} & \multicolumn{3}{|c|}{ Nitrogen $(\mathbf{N})$} & \multicolumn{3}{|c|}{ Phosphorus $\left(\mathrm{P}_{2} \mathrm{O}_{5}\right)$} & \multicolumn{3}{|c|}{ Potassium $\left(\mathrm{K}_{2} \mathrm{O}\right)$} \\
\hline & $\begin{array}{c}\text { Level (kg } \\
\left.\quad \text { ha }^{-1}\right)\end{array}$ & $\begin{array}{c}\text { Response } \\
\text { (kg) }\end{array}$ & $\begin{array}{c}\text { Response } \\
\text { Ratio } \\
\left(\mathrm{kg} \mathrm{kg}^{-1}\right)\end{array}$ & $\begin{array}{c}\text { Level } \\
\left(\mathrm{kg} \mathrm{ha}^{-1}\right)\end{array}$ & $\begin{array}{c}\text { Response } \\
\text { (kg) }\end{array}$ & $\begin{array}{c}\text { Response } \\
\text { Ratio } \\
\left(\mathrm{kg} \mathrm{kg}^{-1}\right)\end{array}$ & $\begin{array}{c}\text { Level } \\
\left(\mathrm{kg} \mathrm{ha}^{-1}\right)\end{array}$ & $\begin{array}{c}\text { Response } \\
\text { (kg) }\end{array}$ & $\begin{array}{c}\text { Response } \\
\text { Ratio } \\
\left(\mathrm{kg} \mathrm{kg}^{-1}\right)\end{array}$ \\
\hline 1. & 100 & 957 & 9.57 & 40 & 336 & 8.41 & 40 & 331 & 7.92 \\
\hline 2. & 200 & 1990 & 9.95 & 80 & 717 & 9.00 & 80 & 615 & 7.68 \\
\hline 3. & 300 & 3100 & 10.33 & 120 & 1244 & 10.37 & 120 & 1303 & 9.70 \\
\hline
\end{tabular}


Table.4 Basic Parameters for maize on Vertisol

\begin{tabular}{|c|c|c|c|c|}
\hline \multirow{2}{*}{ Nutrients } & \multicolumn{4}{|c|}{ Basic data } \\
\hline $\mathbf{N}$ & $\mathbf{N R}\left(\mathbf{q} \mathbf{~ h a}^{-\mathbf{1}}\right)$ & $\mathbf{C}_{\mathbf{S}}(\boldsymbol{\%})$ & $\mathbf{C}_{\mathbf{f}}(\mathbf{\%})$ & $\mathbf{C}_{\mathbf{f y m}}(\mathbf{\%})$ \\
\hline $\mathbf{P}_{\mathbf{2}} \mathbf{O}_{\mathbf{5}}$ & 2.08 & 43.01 & 55.00 & 49.01 \\
\hline $\mathbf{K}_{\mathbf{2}} \mathbf{O}$ & 0.73 & 44.03 & 49.83 & 19.71 \\
\hline
\end{tabular}

Table.5 Ready reckoner of fertilizer doses at varying soil test values for specific yield targets of maize on Vertisol

\begin{tabular}{|c|c|c|c|c|c|c|}
\hline Parameter & $\begin{array}{l}\text { NPK alone } \\
\left(\mathrm{kg} \mathrm{ha}^{-1}\right)\end{array}$ & $\begin{array}{c}\text { NPK+FYM } \\
\text { @ 12.5 t } \\
\mathrm{ha}^{-1}\end{array}$ & $\begin{array}{l}\text { Reduction } \\
\text { over NPK } \\
\text { alone (\%) }\end{array}$ & $\begin{array}{l}\text { NPK alone } \\
\left(\mathrm{kg} \mathrm{ha}^{-1}\right)\end{array}$ & $\begin{array}{c}\text { NPK+FYM } \\
@ 12.5 \mathrm{t} \\
\mathrm{ha}^{-1}\end{array}$ & $\begin{array}{l}\text { Reduction } \\
\text { over NPK } \\
\text { alone (\%) }\end{array}$ \\
\hline & \multicolumn{3}{|c|}{ Grain yield target $\left(10 \mathrm{t} \mathrm{ha}^{-1}\right)$} & \multicolumn{3}{|c|}{ Grain yield target $\left(11 \mathrm{t} \mathrm{ha}{ }^{-1}\right)$} \\
\hline \multicolumn{7}{|c|}{$\mathrm{KMnO}_{4}-\mathrm{N}\left(\mathrm{kg} \mathrm{ha}^{-1}\right)$} \\
\hline 180 & 238 & 193 & 19 & 275 & 230 & 16 \\
\hline 200 & 222 & 177 & 20 & 260 & 215 & 17 \\
\hline 220 & 206 & 161 & 22 & 244 & 199 & 18 \\
\hline 240 & 191 & 146 & 23 & 229 & 184 & 20 \\
\hline 260 & 175 & 130 & 26 & 213 & 168 & 21 \\
\hline 280 & 160 & 115 & 28 & 197 & 152 & 23 \\
\hline 300 & 144 & 99 & 31 & 182 & 137 & 25 \\
\hline \multicolumn{7}{|c|}{ Olsen-P $\left(\mathrm{kg} \mathrm{ha}^{-1}\right)$} \\
\hline 10 & 127 & 105 & 17 & 142 & 119 & 15 \\
\hline 12 & 123 & 101 & 18 & 137 & 115 & 16 \\
\hline 14 & 119 & 97 & 18 & 133 & 111 & 17 \\
\hline 16 & 115 & 92 & 19 & 129 & 107 & 17 \\
\hline 18 & 111 & 88 & 20 & 125 & 103 & 18 \\
\hline 20 & 107 & 84 & 21 & 121 & 99 & 18 \\
\hline 22 & 103 & 80 & 21 & 117 & 95 & 19 \\
\hline \multicolumn{7}{|c|}{$\mathrm{NH}_{4} \mathrm{OAc}-\mathrm{K}\left(\mathrm{kg} \mathrm{ha}^{-1}\right)$} \\
\hline 400 & 123 & 91 & 25 & 141 & 109 & 22 \\
\hline 425 & 120 & 87 & 26 & 137 & 105 & 22 \\
\hline 450 & 116 & 84 & 27 & 134 & 102 & 23 \\
\hline 475 & 113 & 80 & 27 & 130 & 98 & 23 \\
\hline 500 & 109 & 77 & 28 & 127 & 95 & 24 \\
\hline 525 & 106 & 73 & 29 & 123 & 91 & 24 \\
\hline 550 & 102 & 70 & 30 & 120 & 88 & 26 \\
\hline
\end{tabular}

Based on the fertilizer prescription equations the ready reckoners (nomograms) were prepared for desired yield target of 9.0, 10.0 and $11.0 \mathrm{tha}^{-1}$ of maize for a range of soil test values for Vertisol under NPK alone and IPNS. From the perusal of the ready reckoner 
in Table 5, it can be observed that the fertilizer requirement to attain a desired yield target of maize decreased with increase in soil test values and increased with increase in yield targets. The fertilizer doses required for an average soil test value of 180, 22 and 550 $\mathrm{kg} \mathrm{ha}^{-1}$ ofKMnO $\mathrm{K}_{4}-\mathrm{N}$, Olsen-P and $\mathrm{NH}_{4} \mathrm{OAc}-$ $\mathrm{K}$, the quantity of fertilizer $\mathrm{N}, \mathrm{P}_{2} \mathrm{O}_{5}$ and $\mathrm{K}_{2} \mathrm{O}$ for an yield target of 10 and $11 \mathrm{t} \mathrm{ha}^{-1}$ was 238 , 103 and $102 \mathrm{~kg} \mathrm{ha}^{-1}$ and 275,117 and $120 \mathrm{~kg}$ $\mathrm{ha}^{-1}$, respectively. Concurrently, when FYM (25\% moisture and $0.54,0.26$ and $0.53 \%$ of $\mathrm{N}, \mathrm{P}$ and $\mathrm{K}$ ) was applied @ $12.5 \mathrm{t} \mathrm{ha}^{-1}$ along with fertilizer $\mathrm{NPK}$, the required $\mathrm{N}, \mathrm{P}_{2} \mathrm{O}_{5}$ and $\mathrm{K}_{2} \mathrm{O}$ doses were 193, 80 and 70 and 230, 95 and $88 \mathrm{~kg} \mathrm{ha}^{-1}$ for yield target of 10 and $11 \mathrm{t}$ $\mathrm{ha}^{-1}$, respectively. Therefore under IPNS (NPK+FYM@12.5 t ha ${ }^{-1}$ ), 45, 22 and $32 \mathrm{~kg}$ of fertilizer $\mathrm{N}, \mathrm{P}_{2} \mathrm{O}_{5}$ and $\mathrm{K}_{2} \mathrm{O}$ respectively could be reduced from the recommended dose of fertilizers for a specific soil test value and yield target resulting in economy of fertilizer use. Therefore, the integrated use of FYM along with NPK fertilizer not only maximized of yield but also accelerated the profitability. It also improved the soil fertility by the way of increased microbial population and also favorable soil physical properties, thereby conserve the soil fertility for long time. In the present study also, these factors contributed the improvement in yield of maize by the integrated use of NPK along with FYM. In recent times, the fertilizer recommendations derived from STCR approaches may be more appropriate than other approaches.

Realizing the above fact, Santhi et al., (2017) documented a hand book on soil test and yield target based fertilizer prescriptions under IPNS for cereals, millets pulses, oilseeds, sugarcane, cotton, vegetables, spices, and medicinal plants on 17 soil series for Tamil Nadu. The desired target were achieved when the soil test based fertilizer application are prescribed to the farmers. With this back ground, in the present investigation, soil test based fertilizer prescription equations for desired yield target of maize was developed using the basic parameters obtained.

The soil test based IPNS provide positive effect of increased yield which may be due to their effect on root growth, nutrient uptake, simulation of many different enzymes related photosynthesis, efficient response to plant nutrient requirement, integrated supply of nutrients from different sources and improved nutrient supply. The targeted yield equations based on soil tests will not only ensure sustainable crop production but also steer the farmers towards economic use of costly fertilizer inputs (Tegegnework et al., 2015). These findings are in conformity with those reported by Santhi et al., (2011) on Alfisol and by Udayakumar and Santhi (2017) on Inceptisol in pearl millet. Srivastava et al., (2017) and Vedhika Sahu et al., (2017) reported the enhanced yield of rice on Vertisol of Chhattisgarh.

In the present investigation, Soil Test Crop Response based Integrated Plant Nutrition System for desired yield targets of maize has been developed for deep black calcareous, Pilamedu soil series (Typic Haplustert) of Tamil Nadu. The targeted yield approach of fertilizer prescription ensures nutrient balancing to suit desired yield targets based on resource availability of the farmer with sustained soil fertility.

\section{References}

Dey, P. and Bhogal, N.S. (2016). Progress Report of the All India Coordinated research Project for Soil Test Crop Response (2013-16), Indian Institute of Soil Science, Bhopal. pp. 1-260.

Giri Y.Y and Ramana Reddy, D.V. (2015).Phosphorous recommendation for yield targets of kharif maize based on soil test crop response studies. 
Journal of Emerging Technologies and Innovative research, 2(3): 779-780.

Hanway, J.J. and Heidal H. (1952). Soil analysis methods as used in Iowa State College. Agriculture Bulletin.57: 1-13.

Humphries, E.C. (1956). Mineral components and ash analysis. Modern methods of plant analysis. Springer-Verlag, Berlin 1: 468-562.

Olsen, S.R, Cole, C.V and Watanabe. F.S. (1954). Estimation of Available Phosphorous in Soils by Extraction with Sodium Bicarbonate. p. 939. Circular US Dept. of Agriculture, 1400 Independence Ave. S.W., Washington DC.

Piper, C.S. (1966). Soil and Plant analysis, Hans Publications, Bombay.

Ramamoorthy, B., Narasimham, R.K. and Dinesh, R.S. (1967). Fertiliser application for specific yield targets on Sonora 64 (wheat). Indian Fmg.17: 4345.

Santhi, R., Sellamuthu, K.M., Maragatham, S., Natesan, R., Arulmozhiselvan, K., Kumar, K. and Dey, P. 2017. Soil Test and Yield Target based Fertiliser Prescriptions for Crops - An Overview of Outreach Activities in Tribal villages of Tamil Nadu, AICRP-STCR, Department of Soil Science and Agricultural Chemistry, Tamil Nadu Agricultural University, Coimbatore-3, TNAU Offset \& Printing Press, Coimbatore. pp. 1-214.

Shreenivas B.V, Ravi M.V and Latha H.S. (2017). Effect of targeted yield approaches on growth, yield, yield attributes and nutrient uptake in maize (Zea mays L.)-chickpea (Cicer arietinum L.) cropping sequence in UKP command area of Karnataka. An Asian Journal of Soil Science, 12:143150.

Sidharam Patil, P.K. Basavaraja, V.R. Ramakrishna Parama, T.
Chikkaramappa and Sheshadri, T. 2017. Effect of Different Sources and Levels of $\mathrm{K}$ on Maize (Zea mays L.) Yield, Nutrient Content and Uptake by Maize Crop in Low K Soils of Eastern Dry Zone of Karnataka. Int.J.Curr. Microbiol.App.Sci. 6(8): 577-587.

Sivaranjan C, Sellamuthu K.M, Santhi R and Maragatham S. (2018). Effect of graded levels of fertilizers with FYM on yield and NPK uptake by hybrid maize in Verticustropept. Int.J.Curr.Micrbiol. App.Sci, 7(4): 3494-3498.

Srivastava L.K, Mishra V.N and Jatav G.K. (2017). Rice response to fertilizer nutrients as influenced by integrated nutrient management in Vertisols of Chhattisgarh plain, India. system for pearl millet. Research on crops, 18(1): 21-18.

Subbiah, B.V. and G.L. Asija. (1956). A rapid procedure for estimation of available nitrogen in soils. Curr. Sci., 25: 259260.

Tegegnework G.W, Shanwad U.K, Desai B.K, Koppalakar B.G, Shankergoud I and Wubayehu G.W. (2015). Response of soil test crop response (STCR) approach as an optimizing. Plant nutrient supply on yield and quality of sunflower (Helianthus annuиs L.) African. Journal of Agricultural Research, 10(29): 2855-2858.

Truog, E. (1960). Fifty years of soil testing. Transactions Seventh International Congress Soil Science. 3: 46-57.

Udayakumar S and Santhi R. (2017). Soil test based integrated plant nutrition system for pearl millet. Research on crops, 18(1): 21-18.

Vedhika Sahu, Srivastava L.K, Mishra V.N. (2017). Soil test based fertilizer prescription through integrated nutrient management using targeted yield approach for SRI rice (Var.swarna) in Vertisols of Chhattisgargh, India. 
Int.J.Curr.Micrbiol.App.Sci, 6(9): 28242835.

Veeranna G and Srijaya T. (2017) Soil test based fertilizer recommendations for targeted yields of rabi maize (Zea mays) in Vertisols of Telengana state. International Journal of Agricultural Research, 7(4): 689-696.

\section{How to cite this article:}

Suresh, R. and Santhi, R. 2018. Soil Test Crop Response Based Integrated Plant Nutrition System for Maize on Vertisol. Int.J.Curr.Microbiol.App.Sci. 7(08): 1631-1641. doi: https://doi.org/10.20546/ijcmas.2018.708.187 